\title{
ISOLATION OF ARBOR VIRUSES FROM MOSQUITOES COLLECTED AT LIVE-STOCK PENS IN GUMMA PREFECTURE IN 1959*
}

\author{
*TAtsuo MATSUYAMA, **AKIRA OYA, **TAKAyUKi OGATA, \\ **ICHIRO KOBAYASHI, *TADAYOSHI NAKAMURA, \\ *** MitSUO TAKAHASHI AND **MASAMI KITAOKA \\ *Gumma Prefectural Institute of Health, Maebashi, Gumma; **Department of \\ Virology \& Rickettsiology, National Institute of Health, Tokyo; ***Department \\ of Medical Entomology, National Institute of Health, Tokyo
}

(Received: November 21st, 1960)

Hitherto Japanese B encephalitis (JBE) virus has been isolated in many instances from men, animals and mosquitoes and it has been thought probable that JBE virus is the only prevalent arbor virus in Japan. In the meantime, Ando et al. (1952) reported the isolation of a virus (Negishi virus) from the autopsied brain of a patient clinically diagnosed as JBE. By our recent studies, evidences have been accumulated which indicate that Negishi is a member of Group B virus bearing antigen closely related with Russian Spring Summer Encephalitis virus. However, neither virus isolation nor discovery of a human infection has been reported ever since 1949. More recently, Scherer (1958) reported that he could isolate a new Group A virus (Sagiyama virus) from mosquitoes in Saitama, Japan.

Taking those facts in account, it seems important to pursue the distribution of arbor viruses present in Japan over a period of years, hoping that such an investigation might give a clue to learn the ecology of arbor virus in nature. In a limited area, Gumma Prefecture, an investigation was started to gain detailed informations on the yearly appearance of arbor virus in arthropod. The present paper reveals the resuls obtained in the first year on the infection of mosquitoes in summer. The details of the isolation of 3 arbor viruses including a new one will be presented.

\section{GEOGRAPHYCAL, TOPOGRAPHYCAL AND EPIDEMIOLOGICAL Characters of GUMma PREFEcture}

Gumma Prefecture occupies the north-west part of Kanto district, a hundred miles apart from Tokyo City. It extends in N. La. $36^{\circ}-37^{\circ}$ (i. e. $150 \mathrm{~km}$ ) and in E. Lo. $138^{\circ} 15^{\prime}-139^{\circ} 45^{\prime}$ (i.e. $120 \mathrm{~km}$ ). Mountains $(3,000-6,000 \mathrm{ft}$ in height) occupy $4 / 5$ and plane $1 / 5$ of the area. The plane includes mulberry plant, well irrigated rice field and swampy areas as seen in Fig. 1. The population in the prefecture is 1,608,000. Farmers commonly keep domestic animals, hens, pigs, cows and horses. A nestling point of egrets

\# This work was aided by The Rockefeller Foundation, Grant No. 58064. 松山達夫・中村忠義（群馬県衛生研究所）

大谷 明・緒方隆幸・小林一郎・北岡正見（国立予防衛生研究所リヶッチアウィルス部） 高橋三雄（国立予防衛生研究所衛生昆虫部） 


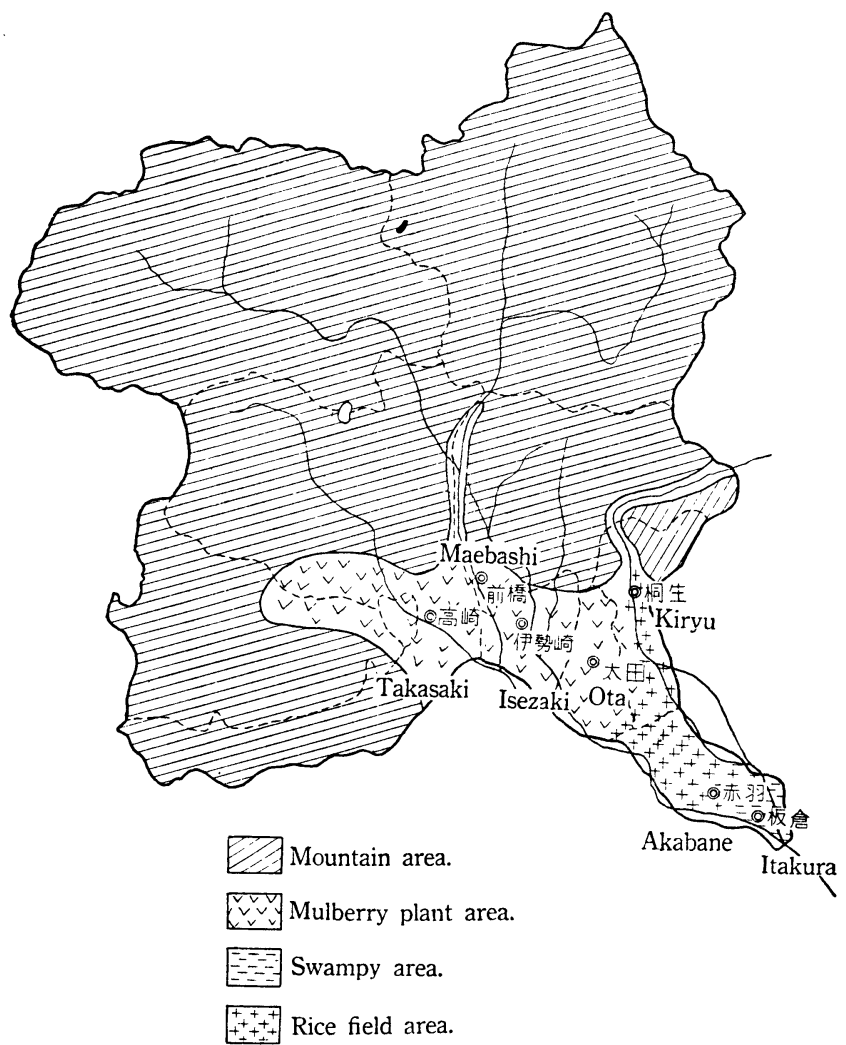

Fig. 1. Topography of Gumma prefecture.

and herons is found near Takasaki and thousands of birds migrate in summer every year. In the year 1958, 81 human cases were reported as JBE, mostly in the plane area. They occurred exclusively in summer from July to September. Among them 36 (44\%) were confirmed as JBE serologically (Fig. 2).

\section{MATERIALS AND METHODS}

Collection of mosquitoes: In the plane, 6 places were selected as sites of mosquito collection, i. e. Takasaki, Kiryu, Isezaki, Ota, Akabane and Itakura (Figs. 1 and 2). From the end of July to the middle of September, mosquitoes were caught by sucking tubes from walls of live-stock pens, keeping mainly cattles, pigs and horses at night from 7.30 to $8.30 \mathrm{pm}$. The collected mosquitoes were kept alive one night and were brought to the station laboratory at the Gumma Prefectural Institute, Maebashi. They were classified and stored in a dry ice box until virus isolation.

Isolation of virus: Mosquitoes of approximately 100 for each species were emulsified in a mortar by adding $2 \%$ normal rabbit serum saline containing penicillin 500 units/cc and streptomycin $500 \mu \mathrm{g} / \mathrm{cc}$. Volume of diluent varied for each species; for 100 mosquitoes, C. tritaeniorhyhchus $2.0 \mathrm{cc}$, C. pipiens $4.0 \mathrm{cc}$, C. bitaeniorhynchus $4.0 \mathrm{cc}$, Mansonia uniformis $4.0 \mathrm{cc}$, A. vexans 6.0 cc to $8.0 \mathrm{cc}$, Armigeres $8.0 \mathrm{cc}$, and Anopheles $8.0 \mathrm{cc}$. Those concentrations of mosquitoes were found to avoid toxic effects upon suckling mouse brain. The suspensions were held at $4^{\circ} \mathrm{C}$ for 2 hours and centrifuged at 3,000 rpm for 10 minutes in cold room. Two hundredth $\mathrm{cc}$ of the supernate was inoculated i. c. into suckling mice. For each pool of mosquitoes, 2 litters of 2 to 4 day old suckling mice (dd strain) were used. The mice were observed daily for 10 days and brains 
were harvested from sick mice when they became moribund. The harvested brains were tested for bacterial and mycotic contaminations with thioglycolate medium and stored at $-70^{\circ} \mathrm{C}$.

Identification of virus isolates: Identification studies were carried out in the National Institute of Health by hemagglutination-inhibition and complement fixation tests. JBE virus strains were identified at their 3rd passage levels. Details of the identification studies of viruses other than JBE virus will be described in a separate paper (Oya et al.,19ô1).

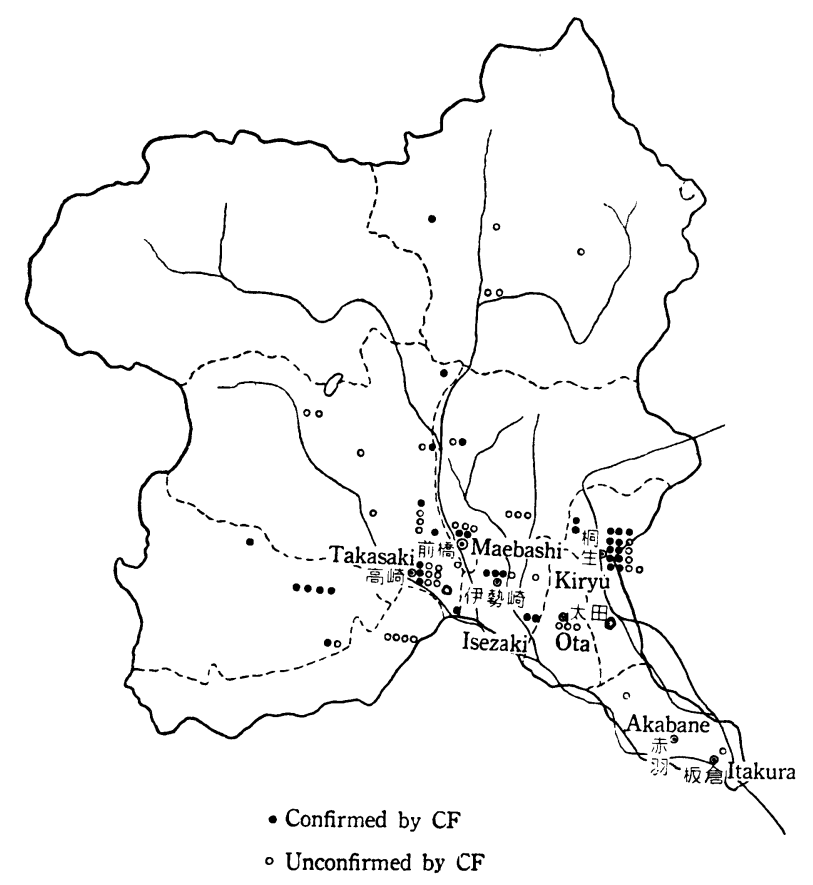

Fig. 2. Incidence of Japanese B encephalitis patient in 1958. (reported cases).

\section{RESULTS}

\section{Number and Species of Mosquitoes Collected}

In total, 52,641 mosquitoes were collected at the whole study sites; 13,815 at Itakura, 10,680 at Takasaki, 8,790 at Kiryu, 7,212 at Ota, 7,059 at Akabane and 5,085 at Isezaki. Mosquito species were as follows:

Culex (Culex) tritaeniorhynchus Giles

Culex (Culex) pipiens (Linnaeus)

Culex (Culex) bitaeniorhynchus Giles

Culex (Lutzia) vorax Edwards

Aedes (Aedimorphus) vexans nipponii (Theobald)

Aedes (Stegomyia) albopictus (Skuse)

Armigeres (Armigeres) subalbatus (Coquillett)

Anopheles (Anopheles) spp.

Mansonia (Mansonioides) uniformis (Theobald) 
Table 1. Number and species of mosquitoes collected at live-stock pens in Gumma in 1959

\begin{tabular}{|c|c|c|c|c|c|c|c|c|c|}
\hline \multirow{2}{*}{$\begin{array}{c}\text { Date } \\
\text { collected }\end{array}$} & \multicolumn{4}{|c|}{ Culex } & \multicolumn{2}{|c|}{ Aedes } & \multirow{2}{*}{$\begin{array}{l}\text { Armi- } \\
\text { geres }\end{array}$} & \multirow{2}{*}{$\begin{array}{l}\text { Ano- } \\
\text { pheles }\end{array}$} & \multirow{2}{*}{$\begin{array}{l}\text { Man- } \\
\text { sonia }\end{array}$} \\
\hline & tritaen. & pipiens & bitaen. & vorax & vexans & albo & & & \\
\hline \multirow[t]{3}{*}{ July 281959} & 702 & $120(12)$ & 0 & 0 & $249(1)$ & 2 & 51 & 361 & 0 \\
\hline & 1,174 & $275(9)$ & 8 & 0 & 474 & 0 & $25(10)$ & 601 & 0 \\
\hline & 1,821 & $338(59)$ & 45 & 0 & 470 & 2 & 15 & 902 & 0 \\
\hline Aug. 11 & 646 & $374(49)$ & 30 & 0 & 167 & 0 & 18 & 257 & 0 \\
\hline 12 & $1,278(1)$ & 279 & 22 & 0 & 234 & 1 & 10 & 689 & 0 \\
\hline 13 & $324(3)$ & $167(44)$ & 10 & 0 & 33 & 0 & 20 & 270 & 0 \\
\hline 18 & 254 & $124(18)$ & 2 & 0 & 288 & 0 & $30(4)$ & 75 & 0 \\
\hline 19 & 966 & $223(23)$ & 9 & 0 & 866 & 0 & $25(6)$ & 127 & 0 \\
\hline 20 & 854 & $362(30)$ & 4 & 0 & 1,761 & 2 & $55(2)$ & 280 & 0 \\
\hline 25 & 680 & $287(7)$ & 3 & 1 & 742 & 2 & $75(1)$ & 327 & 0 \\
\hline 26 & 989 & $282(4)$ & 9 & 0 & 829 & 0 & 49 & 838 & 9 \\
\hline 27 & 1,299 & $232(49)$ & 10 & 1 & 435 & 1 & $70(5)$ & 211 & $10(1)$ \\
\hline Sept. 1 & 1,248 & $287(15)$ & $18(1)$ & 0 & 677 & 1 & $65(1)$ & 1,116 & 16 \\
\hline 2 & 1,582 & $275(13)$ & 3 & 0 & 749 & 1 & $50(4)$ & 1,177 & 4 \\
\hline 3 & 1,680 & $356(6)$ & 9 & 0 & $404(1)$ & 3 & $124(65)$ & $570(4)$ & 18 \\
\hline 8 & $1,102(1)$ & $124(3)$ & 5 & 0 & 1,680 & 0 & $120(36)$ & 1,789 & 9 \\
\hline 9 & 1,072 & $128(16)$ & 4 & 0 & 1,262 & 0 & $85(9)$ & 2,306 & 12 \\
\hline 10 & 1,129 & $273(29)$ & 19 & 0 & 1,641 & 2 & $33(7)$ & 2,683 & $15(1)$ \\
\hline Total & 18,805 & 4,895 & 211 & 21 & 12,963 & 17 & 1,070 & 14,583 & 95 \\
\hline
\end{tabular}

Grand total 52,641

Note: Numbers in parenthesis denote the numbers of male mosquitoes.

Number of mosquitoes collected at each period are listed in Table 1. These numbers do not seem to reflect the real distribution of mosquitoes of live-stock pens, since some selection was made by collectors when they found a large number of mosquitoes.

\section{Properties of New Arbor Virus Isolates}

In general, 47 strains of arbor virus were isolated from 407 pools of mosquitoes. Among them, 39 were identical to JBE virus. The other 8 strains had biological characters remarkably different from that of JBE virus. Six strains out of 8 were found to be virulent to adult mice as well as to suckling mice showing an i. c. infective titer of $10^{7.2}$ in the adult and $10^{7.6}$ in the suckling. The incubation period found in the adult mice was 3 to 5 days and that in the suckling 2 to 3 days. Identification studies furnished evidences that those 6 were identical with each other and neither belonged to Group A or Group B virus nor related with any other ungrouped arbor viruses tested. On the other hand, they were found to have such common properties of arbor virus as agglutination of one day chick or goose erythrocytes, inactivation with desoxycholate (Theiler, 1957) and resistance against precipitation by protamine sulphate (Warren et al., 1949). They were temporarily designated as Akabane virus.

The remaining two strains showed a very low virulence even in the suckling mouse 
brain $\left(10^{2.0}\right.$ to $\left.10^{3.0}\right)$. Incubation period was around 7 days after inoculation. Adult mice inoculated i. c. with this virus manifested no symptom, while the immune serum against this virus contained common antibody against Group A virus, and finally this virus was considered to be closely related with Sagiyama (Scherer, 1958) and AMM 2021 (Buescher, 1959) viruses, though possessing a different pathogenicity to the mouse.

Table 2. Isolation of Japanese B encephalitis virus from mosquitoe-pools

\begin{tabular}{|c|c|c|c|c|c|}
\hline \multirow{2}{*}{\multicolumn{2}{|c|}{ Date collected }} & \multicolumn{2}{|c|}{ Culex } & \multirow{2}{*}{ Aedes } & \multirow{2}{*}{$\begin{array}{c}\text { Other } \\
\text { mosquitoes }\end{array}$} \\
\hline & & tritaen. & pipiens & & \\
\hline July & $28,29,30$ & $* 7 / 41 \quad(17.1 \%)$ & $0 / 6$ & $0 / 12$ & $0 / 16$ \\
\hline \multirow[t]{3}{*}{ Aug. } & $11,12,13$ & $3 / 19(15.8 \%)$ & $0 / 7$ & $0 / 5$ & $0 / 9$ \\
\hline & $18,19,20$ & $6 / 18(33.3 \%)$ & $1 / 6(16.7 \%)$ & $0 / 27$ & $0 / 5$ \\
\hline & $25,26,27$ & $8 / 27 \quad(29.6 \%)$ & $0 / 4$ & $0 / 20$ & $0 / 11$ \\
\hline \multirow[t]{2}{*}{ Sept. } & $1, \quad 2, \quad 3$ & $8 / 35 \quad(22.9 \%)$ & $0 / 4$ & $0 / 16$ & $0 / 15$ \\
\hline & $8, \quad 9,10$ & $6 / 29(20.7 \%)$ & $0 / 5$ & $0 / 40$ & $0 / 28$ \\
\hline & Total & $38 / 169(22.5 \%)$ & $1 / 32(3.1 \%)$ & $0 / 120$ & $0 / 84$ \\
\hline
\end{tabular}

Note: Denominators show number of mosquito-pools tested. Numerators mean number of virus-positive pools. One pool consisted of about 100 mosquitoes.

\section{Isolation of JBE Virus}

Thirty eight out of 39 strains of JBE virus were isolated from C. tritaeniorhynchus and only one strain from $C$. pipiens. No JBE virus was obtained from other species. As indicated in Table 2, JBE virus was recovered throughout the collection period. The peak of mosquito infection was demonstrated in the middle of August when a portion as high as $33 \%$ of the pools was found positive. In addition, JBE virus was obtained at all study sites except Akabane.

\section{Isolation of Akabane Virus}

Among 6 strains of Akabane virus, 4 were obtained from $A$. vexans and 2 from $C$. tritaeniorhynchus. None of other species yielded Akabane virus in the present study. Mosquito infection was limited to the middle and end of August (Table 3). The places yielding Akabane virus were; Akabane (2 strains), Itakura, Ota, Kiryu and Takasaki (1 strain from each).

\section{Isolation of Itakura Virus}

Two strains of Itakura virus were isolated from $A$. vexans and all were obtained from Itakura (Table 4).

\section{DISCUSSION}

As expected beforehand, JBE virus was isolated most frequently from mosquitoes. Isolation was successful through the period of from the end of July to the middle of 
Table 3. Isolation of Akabane virus from mosquito-pools

\begin{tabular}{|c|c|c|c|c|c|}
\hline \multirow{2}{*}{\multicolumn{2}{|c|}{ Date collected }} & \multicolumn{2}{|c|}{ Culex } & \multirow{2}{*}{$\begin{array}{l}\text { Aedes } \\
\text { vexans }\end{array}$} & \multirow{2}{*}{$\begin{array}{c}\text { Other } \\
\text { mosquitoes }\end{array}$} \\
\hline & & tritaen. & pipiens & & \\
\hline July & $28,29,30$ & $* 0 / 41$ & $0 / 6$ & $0 / 12$ & $0 / 16$ \\
\hline \multirow[t]{3}{*}{ Aug. } & $11,12,13$ & $0 / 19$ & $0 / 7$ & $0 / 5$ & $0 / 9$ \\
\hline & $18,19,20$ & $1 / 18(5.6 \%)$ & $0 / 6$ & $1 / 27(3.7 \%)$ & $0 / 5$ \\
\hline & $25,26,27$ & $1 / 27(3.7 \%)$ & $0 / 4$ & $3 / 20(15.0 \%)$ & $0 / 11$ \\
\hline \multirow[t]{3}{*}{ Sept. } & $1, \quad 2, \quad 3$ & $0 / 35$ & $0 / 4$ & $0 / 16$ & $0 / 15$ \\
\hline & $8, \quad 9,10$ & $0 / 29$ & $0 / 5$ & $0 / 40$ & $0 / 28$ \\
\hline & Total & $2 / 169(1.2 \%)$ & $0 / 32$ & $4 / 120(3.3 \%)$ & $0 / 84$ \\
\hline
\end{tabular}

* The same to Table 2 .

Table 4. Isolation of Itakura virus from mosquito-pools

\begin{tabular}{|c|c|c|c|c|c|}
\hline \multirow{2}{*}{\multicolumn{2}{|c|}{ Date collected }} & \multicolumn{2}{|c|}{ Culex } & \multirow{2}{*}{$\begin{array}{l}\text { Aedes } \\
\text { vexans }\end{array}$} & \multirow{2}{*}{$\begin{array}{l}\text { Other } \\
\text { mosquitoes }\end{array}$} \\
\hline & & tritaen. & pipiens & & \\
\hline July & $28,29,30$ & $* 0 / 41$ & $0 / 6$ & $0 / 12$ & $0 / 16$ \\
\hline \multirow[t]{3}{*}{ Aug. } & $11,12,13$ & $0 / 19$ & $0 / 7$ & $0 / 5$ & $0 / 9$ \\
\hline & $18,19,20$ & $0 / 18$ & $0 / 6$ & $0 / 27$ & $0 / 5$ \\
\hline & $25,26,27$ & $0 / 27$ & $0 / 4$ & $1 / 20(5.0 \%)$ & $0 / 11$ \\
\hline \multirow[t]{2}{*}{ Sept. } & $1, \quad 2, \quad 3$ & $0 / 35$ & $0 / 4$ & $0 / 16$ & $0 / 15$ \\
\hline & $8, \quad 9,10$ & $0 / 29$ & $0 / 5$ & $1 / 40 \quad(2.5 \%)$ & $0 / 28$ \\
\hline & Total & $0 / 169$ & $0 / 32$ & $2 / 120(1.7 \%)$ & $0 / 84$ \\
\hline
\end{tabular}

* The same to Table 2 .

August. The infection rate of $C$. tritaeniorhynchus was fairly high from the beginning of the present study and seemed to have attained a peak toward the end of August. At the peak, one out of $300 \mathrm{C}$. tritaeniorhynchus was thought to be infected with JBE virus. Such a high incidence of infected mosquitoes seems quite adequate to explain the remakably high incidence of antibody presence in the sera of residents in the epidemic area. An interesting result was noted on the relation of virus to the species of mosquito. With only one exception, JBE virus was isolated exclusively from C. tritaeniorhynchus confirming the results obtained by previous investigators (Mitamura et al., 1938; Hammon et al., 1949). As far as the rural district is concerned, it is no doubt that C. tritaeniorhynchus is a main vector of JBE virus in Japan. However, it is not quite correct to conclude that only a single type of virus transmission mode is responsible for all epidemics occurring in Japan. JBE virus has been isolated heretofore from autopsied materials even in the center of big cities as Tokyo or Yokohama, where C. tritaeniorhynchus seems scanty.

On the other hand, the favorite host of Akabane and Itakura viruses seems to be different from that of JBE virus. Akabane virus was isolated from $A$. vexans as well 
as $C$. tritaeniorhynchus. Itakura virus was isolated only from $A$. vexans, but a similar virus was obtained from $C$. tritaeniorhynchus by Scherer (1958). No other species of mosquito yielded viruses. The reason why there is a limited relation between virus and mosquitoes is still obscure. The difference of the susceptibility or difference of zoophily of mosquitoes might account for this fact.

It is obvious that Akabane virus is a new arbor virus isolated in Japan. As far as we know, nobody succeeded in isolating this virus before. Then a question may arise as to how it appeared in 1959. Also, it is interesting to see whether it would reappear in the following years. There may be many speculations to explain the problem. Anyhow, it is apparent that newly described virus may furnish a good tool for the understanding of the ecology of arbor viruses in Japan. The facts that Itakura virus was isolated only from a swampy area where the migrating birds used to be in plenty and that this virus has close immunological similarity with Malayan virus (AMM 2021) appear to support the idea there must be a close relation between Japan and other countries located in South Asia with regard to arbor virus exchange.

\section{SUMMARY}

A description was made on the arbor virus isolation from mosquitoes collected in summer of 1959 at Gumma, Japan. Out of 47 isolates, 39 were Japanese B encephalitis virus, 2 were Sagiyama-like virus of Group A and 6 were considered to be a new agent. All Japanese B encephalities virus strains were isolated from $C$. tritaeniorhynchus but one from $C$. pipiens. Group A virus strains came from $A$. vexans collected at swampy area. A new agent was isolated from both $C$. tritaeniorhychus and $A$. vexans. No other species of mosquito yielded arbor virus.

The authors with to express their gratitude to Drs. S. Asahina, J. Akiyama, H. Taniguchi, T. Fujikura, the National Institute of Health and Dr. H. Nakagawa, the Institute of Natural Resources for their cooperation. They are also indebted to Dr. S. Komiyama, the Department of Public Health and Welfare of Gumma Prefecture, Dr. K. Arai, C. Sato, M. Kanazawa, I. Fukushima, T. Yamaguchi, Chiefs of the Health Centers in Gumma, Dr. K. Murata, the Medical Association of Takasaki City for their extensive support to this investigation, and to Miss. S. Tsuchiya for her valuable assistance.

\section{REFERENCES}

Ando, K., Kuratsuka, K., Arima, S., Hironaka, N., Honda, Y. \& Ishil, K. (1952) : Studies on the viruses isolated during epidemic of Japanese B encephalitis in 1948 in Tokyo area. Kitasato Arch. Exper. Med., 24, 49-61.

BuEsCHER, E. L. (1959) : Personal communication.

Hammon, W. M., Tiggert, W. D., SAther, G. E. \& Schenker, H. (1949) : Isolation of Japanese B encephalities virus from naturally infected Culex tritaeniorhynchus collected in Japan. Am. J. Hyg., 50, 51-56.

Mrtamura, T., Kitaoka, M., Mori, K. \& OKUbo, K. (1938) : Isolation of Japanese encephalitis virus from mosquitoes collected in nature. "Tokyo Ijishinshi", 62, 820-824.

Oya, A., Okuno, T., Ogata, T. \& Kobayashi, I. (1961): To be published.

SCHERER, W. F. (1958) : Annual Report (1958 March-1960 Feb.), Dept. Bact. \& Immunol. Univ. Minnesota.

Theiler, M. (1957) : Action of sodium desoxycholate on arthropod-borne viruses. Proc. Soc. Exper. Biol. \& Med., 96, 380-382. 
Warren, J., Weil, M. L., Russ, S. B. \& Jeffries, H. (1949): Purification of certain viruses by use of protamine sulphate. Proc. Soc. Exper. Biol. \& Med., 72, 662-664. 